\title{
ADHD and Gender: subjective experiences of children in Chile'
}

TDA-H y género: experiencias subjetivas de niños y niñas en Chile

\author{
Pía Uribe ${ }^{a}$ \\ (D) https://orcid.org/0000-0003-3786-2870 \\ E-mail: maria.pia.uribeळgmail.com \\ Gabriel Abarca-Brown ${ }^{a, b}$ \\ (D) https://orcid.org/0000-0001-5369-1616 \\ E-mail: gabriel.abarca_brownळkcl.ac.uk

\section{Esteban Radiszcz ${ }^{\mathrm{a}}$} \\ (D) https://orcid.org/0000-0002-3282-6670 \\ E-mail: eradiszczळuchile.cl

\section{Eleonora López-Contreras ${ }^{a}$} \\ (D) https://orcid.org/0000-0003-0820-7391 \\ E-mail: eleonoralopezcontrerasळgmail.com \\ aUniversidad de Chile, Santiago, Chile.

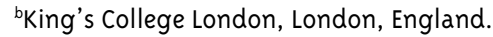

\section{Correspondence}

Pía Uribe

Universidad de Chile, Facultad de Ciencias Sociales, Laboratorio Transdisciplinar en Prácticas Sociales y Subjetividad. Av. Capitán Ignacio Carrera Pinto, 1.045, Ñunoa. Santiago, Chile.

\section{Abstract}

Although research on ADHD has tended to ignore gender differentials, recent contributions produced mainly from epidemiology have revealed that this diagnostic category seems to be strongly related to gender. However, these contributions seem to limit their scope to the study of the symptoms as well as cognitive, affective and social functioning of children, leaving aside subjective aspects associated with the ADHD practices of diagnosis and treatment. Thus, this article aims to explore how the gender dimension crosses the subjective experience of children diagnosed with ADHD. Based on open interviews conducted with children between the ages of 7 and 13, we show general trends that articulate gender and characteristics associated with the ADHD diagnosis, while at the same time, with children's experiences that dislocate such trends. The findings were grouped according to four emerging axes: (1) locations, (2) abilities, (3) approches, (4) interactions. Thus, we will show how the experience of boys and girls is multiple in relation to the diagnosis and it is not possible to be reduced to a gender binary perspective.

Keywords: ADHD; Gender; Subjective Experience; Childhood.

\footnotetext{
This article is part of the research project developed by Laboratorio Transdisciplinar en Prácticas Sociales y Subjetividad (LaPSoS), entitled "Trayectorias de malestar en niñas y niños diagnosticados con Trastorno de Déficit Atencional e Hiperactividad (TDAH): experiencia subjetiva y social de un sufrimiento multiforme”, funded by the Concurso de Fortalecimiento de Productividad y Continuidad en Investigación (FPCI) of the Facultad de Ciencias Sociales of Universidad de Chile, as well as from CONICYT through its Programa de Cooperación Internacional/Apoyo a la Formación de Redes Internacionales entre Centros de Investigación (Contest 2017), Folio REDES170095.
} 
Si bien las investigaciones sobre TDA-H han tendido a dejar los aspectos diferenciales de género en un lugar secundario, recientes contribuciones emanadas principalmente desde la epidemiología han revelado que esta categoría diagnóstica parece estar fuertemente relacionada con el reparto de los géneros. Sin embargo, dichas contribuciones parecen limitar sus alcances al estudio de la sintomatología y funcionamiento cognitivo, afectivo y social de los(as) niños(as), dejando de lado aspectos subjetivos asociados a las prácticas de diagnóstico y tratamiento de TDA-H. De este modo, el objetivo de este artículo es explorar cómo la dimensión de género configura la experiencia subjetiva de niños(as) diagnosticados(as) con TDA-H. A partir de la realización de entrevistas abiertas realizadas a niños entre 7 y 13 años, damos cuenta de tendencias generales que articulan género y características asociadas al diagnóstico de TDA-H, a la vez que, con experiencias infantiles que dislocan tales tendencias. Los resultados se agruparon en función de cuatro dimensiones emergentes del material producido en las entrevistas: (1) localizaciones; (2) habilidades; (3) abordajes; (4) interacciones. Así, mostraremos cómo la experiencia de niños y niñas es múltiple en relación al diagnóstico y no es posible reducirla a una perspectiva binaria en torno al género. Palabras clave: TDA-H; Género; Experiencia Subjetiva; Niñez.
In the context of the so-called "schools driven by results" proper of post-dictatorial Chile (Herrera; Reyes; Ruiz, 2018), the diagnostic category of Attention Deficit Disorder with and without Hyperactivity (ADHD) has become one of the ways of cataloguing behaviors that, considered disruptive, hinder both compliance with academic requirements, as well as socially expected behaviors in children and adolescents. The implementation of school integration policies has played an essential role in the production of identity markers and in the creation of "normality" and "difference" (Matus; Rojas, 2018), which delimit any situation of inequity/ social inequality of a certain group, whether for reasons of disability, race/ethnicity, class and/ or gender (Apablaza, 2017). Thus, the diagnosis of ADHD has become one of those "differences" that are identified in the school context and then led to the creation of specific strategies for its "improvement" (Matus; Rojas, 2018). In fact, since 1998, government strategies developed on ADHD in the country have promoted an intersectoral approach, which integrates both the care of cases in health devices, ${ }^{2}$ either at the primary or secondary level depending on severity, such as the early detection of these and their special consideration in educational establishments. ${ }^{3}$ Indeed, the sophistication of these processes has coincided with a sustained increase in ADHD prevalence rates, which would currently reach $10.3 \%$ of the national child and youth population (De la Barra et al., 2013) and would represent one of the highest in the world.

However, while the diagnosis of ADHD has been conceived, within the inclusion strategies implemented in the educational field in Chile, as a transitory special education need (SEN) by education

\footnotetext{
2 Over the last 20 years, these strategies have been expressed, for example, in the "Normas técnicas para el diagnóstico y tratamiento de los trastornos hipercinéticos en la atención primaria 1997-1998” (Chile, 1998), the "Guía clínica atención integral de niñas/niños y adolescentes con trastorno hipercinético/trastorno de la atención (THA)" (Chile, 2008), and the "Prioridad programática: niñas, niños y adolescentes con trastorno hipercinético / de la atención (THA)" (Chile, 2011).

3 In addition to specific strategies previously adopted in order to support children with ADHD (Chile, 20og), the Programa de Integración Escolar (PIE) (School Integration Program) is the main initiative implemented in the educational field. This is "an educational strategy with an inclusive approach, insofar as its purpose is to encourage the participation and achievement of learning objectives of all students, providing resources and equalizing educational opportunities especially for those who have greater need of support to progress in their learning" [own translation] (Chile, 2017).
} 
policies in Chile, the category seems to have been sparsely questioned from a gender perspective. This is due, in part, to the fact that inclusion policies would have led to the invisibility and neutralization of the discussion on the normalization regimes of subjects, while at the same time they would not consider the incidence of the latter on the articulation of the subjective aspects of children and adolescents (Apablaza, 2017). In other words, policies, institutions, strategies and tactics seem to have differentiated some specific groups of children and adolescents on the basis of certain "identity marks", without examining, at least for the particular case of ADHD, what the specific relations between a transitory SEN and gender or what their subjective effects, would be. In fact, in the academic sphere, studies aimed at observing the distinctive relationships between ADHD and gender seem to be scarce or rather nonexistent.

Although, at the international level, research on ADHD has tended to leave gender differentials aspects in a secondary place, recent contributions coming mainly from epidemiology have shown that the diagnostic category seems to be strongly characterized by its unequal distribution according to sex (Bergey; Conrad, 2018). In the 197os, the proportion of men and women diagnosed with the "hyperactive syndrome" category was 10:1, respectively (Rucklidge, 2010). This ratio would have even favoured ADHD currently being considered a "disorder of boyhood" (Hart; Grand; Riley, 2006; Pollack, 1999), which may represent one of the reasons that have led research to focus predominantly on children (Biederman et al., 2002; Montiel-Nava; Montiel-Barbero; Peña, 2007). The shift from both "psy" and "neuro" disciplines to "attention" over the 80's decade would have resulted in the observed difference in prevalence between men and women decreasing to a ratio of 4:1 or 3:1 in much of Western countries (APA, 2014; Conrad; Singh, 2018). Thus, recent contributions have indicated that it would be a priority to carry out studies capable of examining the gender differences associated with the diagnosis of ADHD, having as a horizon not to reproduce biases or prejudices in their theoreticalmethodological approaches (Gaub; Carlson, 1997; Williamson; Johnston, 2015).
In Chile, specifically, the prevalence of children between the ages of 4 and 11 diagnosed with ADHD follows the global trend with rates of $16.4 \%$ in males and $14.6 \%$ in females. However, in young people between 12 and 18 years old, the prevalence in men would be $2.1 \%$, while in women it would be $6.9 \%$ (De la Barra et al., 2013), inverting the usual ratio and presenting a distribution of 1:3. As Conrad and Singh (2018) argue, while the reason for this rate reversal is not yet clear, the associated causes would probably be the focus on 'inattention' as a discrete symptom of ADHD - as well as other cognitive symptoms attributed to ADHD - rather than behavioral symptoms. According to the opinion of several researchers (Matus; Rojas, 2018; Rojas; Rojas; Peña, 2018), it becomes necessary to conduct studies that, particularly for the Chilean case, consider the existing relations between the ADHD category and the gender dimension.

This article aims to explore how the subjective experience of children diagnosed with ADHD is crossed by the social dimension of gender. However, rather than seeking a possible response to the existing differences in the prevalence rates of the disorder in Chile, we will show how differences are articulated at the level of diagnosis and treatment practices of ADHD from a gender perspective. We therefore assume an orientation that includes diagnosis as a cultural product (Timimi; Taylor, 2004; Timimi et al., 2004) in which subjective experience is shaped by social, cultural, historical, material and relational forces (Biehl; Good; Kleinman, 2007; Blackman et al., 2008).

We will firstly show national and international studies that have linked ADHD and gender. Subsequently, we will describe the qualitative methodological framework that guided the general research in which this article subscribes, as well as the specific materials that gave rise to this work. Thirdly, we will describe the subjective experience of children diagnosed and treated by ADHD, which is ordered according to four dimensions that, extracted from the material provided by the interviewees, concern to: (1) locations; (2) abilities; (3) approaches; and (4) interactions. Finally, we will discuss the multiple forms that the relationship between diagnosis and treatment of children with 
ADHD takes from a gender perspective. Specifically, we will not only analyze the general tendencies that articulate gender and diagnosis of ADHD, but we will also highlight the subjective experiences that dislocate these tendencies. Thus, we will seek to show how the experience of children in relation to diagnosis cannot be reduced to a binary perspective with respect to gender.

\section{Research on ADHD and gender}

Although the diagnosis of ADHD is a cross-gender issue (Hart; Grand; Riley, 20o6), many of the studies that have explored the relationships between ADHD and gender have tended to approach the latter from heteronormative perspectives that reduce the spectrum of gender differences to the male-female dichotomy. Since the early 1990 s, these approaches have attempted to unravel how such differences would operate in both symptomatic - cognitive, affective, and behavioral - and social terms in diagnosed children. Nevertheless, these studies which we will review in detail in the following pages - seem to be marked by an epidemiological and/or psychiatric imprint, tending to leave aside historical, sociocultural and contextual aspects of the subjective experience and its generic articulation.

Some studies have underlined how parents would commonly be in "disagreement", or would show certain "rejection", regarding the "pathological" nature of their children's behavior (Singh; 2004), situating the problem cause in a biological rather than a psychological or social order (Behrouzan, 2016; Nakamura, 2017). In fact, Peter Conrad, in his report titled "Identifying hyperactive children", published in 1976, already indicated that the mother would usually be at the frontline of the medicalization process since this would allow her to qualify the responsibilities that, within certain normative orders of gender, are expected of motherhood. Hence, medicalization practices would have a strong relationship with the expected behaviors for men and women (Hart; Grand; Riley, 2006).

However, although these studies have highlighted some associated contextual aspects, social studies of childhood have denounced that, due to the approaches that have predominated in child mental health research, children would remain in a field of "discursive marginalization” (Peña; Rojas; Rojas, 2015; Vergara et al., 2014; Wodak; Meyer, 2001). The diverse approaches in mental health, and in particular around the ADHD, would not explore in the perspective that the children have with respect to the practices of diagnosis and treatment, leaving their discourses invisible and discouraged (Peña; Rojas; Rojas, 2015).

Hereunder, we will present the main findings of studies focused on the relationships between ADHD and gender. As we mentioned above, these are studies that, developed by disciplines such as epidemiology and psychiatry, have tended to reduce the gender dimension to the sex difference. For this, we will divide these results into three dimensions, namely: (1) cognitive abilities; (2) psychosocial functioning; and (3) psychiatric comorbidity.

\section{Cognitive abilities}

Several studies have shown the presence of clinical differences between boys and girls diagnosed with ADHD. On the one hand, some research has indicated that boys would be mostly affected by problems of disinhibition or impulsivity, while, on the other hand, girls would present problems of inattention and learning, speech and language disorders, as well as problems at the level of their cognitive and intellectual abilities (Gershon, 2002; Hasson; Fine, 2012; Rucklidge, 2006; Seidman et al., 2005; Vélez et al., 2008).

After conducting a meta-analysis of the literature on ADHD and gender differences, Gaub and Carlson (1997) argued that there were no gender differences in aspects such as impulsivity, academic performance, social functioning, fine motor skills, parental education, or parental depression. However, compared to diagnosed children, girls with ADHD presented greater intellectual difficulties, low levels of hyperactivity, and low rates of other behaviors called "externalizing behaviors".

Some gender differences in cognitive abilities seem to be strongly mediated by the effects of the source of derivation (biases and prejudices in 
derivation) (Gaub; Carlson, 1997). In fact, studies carried out in school contexts have argued that teachers would tend to evaluate girls with greater difficulties and needs, determining the processes of derivation (Coles et al., 2012; Hart; Grand; Riley, 2006).

\section{Psychosocial functioning}

In terms of psychosocial functioning, both boys and girls diagnosed with ADHD would have greater difficulties in their social relationships compared to children without ADHD (Mikami; Lorenzi, 2011). Although no gender differences are identified in terms of social relationships between boys and girls with ADHD (Gershon, 2002; Carlson; Tamm; Gaub, 1997), disruptive behaviors would have a greater impact on the peer relationships established by girls (Mikami; Lorenzi, 2011).

While boys would tend to present symptoms such as hyperactivity and inattention - an issue that would lead them to develop a "more maladjusted" socialization profile, with greater negativism and less consideration for others (Biederman et al., 2002) - at the same time they would show greater ease at the level of interpersonal relations, better communication abilities and assertive expression of opinions (Garza-Morales; Núñez-Villaseñor; Vladimirsky-Guiloff, 2007; Newcorn et al., 2001), in addition to better self-esteem and self-concept (Rucklidge; Tannock, 2001).

Girls, on the other hand, although they generally present only symptoms of inattention in their manifestations of ADHD, would tend to establish lower quality interpersonal relationships (Biederman et al., 2002; Blachman; Hinshaw, 2002; Guerrero et al., 2017; Mikami; Lorenzi, 2011; Sciberras; Ohan; Anderson, 2012). In fact, some studies have identified that girls diagnosed with ADHD show greater shyness and withdrawal (Biederman et al., 2002; Guerrero et al., 2017), as well as greater emotional problems and perfectionism as compared to boys (Garza-Morales; Núñez-Villaseñor; VladimirskyGuiloff, 2007). Likewise, it has been identified that girls diagnosed with ADHD tend to establish a limited number of friendships and to form conflictive and aggressive social relationships (Blachman; Hinshaw, 2002), in comparison with undiagnosed girls.

\section{Psychiatric comorbidity}

A meta-analysis on ADHD and gender differences found that there would be differences between boys and girls diagnosed with ADHD and the presence of psychiatric disorders (Gershon, 2002). Although the psychopathological spectrum presented by children is narrower than adult patients who were diagnosed with ADHD in childhood - where it is possible to observe antisocial behaviors, addictions, mood disorders and eating disorders (Biederman et al., 2010) - it is possible to verify the presence of anxiety-depressive disorders, as well as selfaggressive behaviors.

Girls would be more likely to suffer from psychiatric pathologies, specifically depression and anxiety (Dalsgaard et al., 2002; Gershon, 2002; Rucklidge; Tannock, 2001), as well as having higher rates of suicidal ideation than the population without ADHD (Rucklidge; Tannock, 2001). In the same line, adolescent girls with ADHD would perceive themselves as more inefficient, with low self-esteem, and would be more affected by negative life events compared to adolescent boys diagnosed with ADHD (Rucklidge; Tannock, 2001). Rates of depression and anxiety would be higher, especially in adolescents, while physical aggression and so-called "externalizing behaviors" would be lower in girls and adult women with ADHD. However, some of these findings have been questioned in methodological terms by the size of the samples, the presence of certain prejudices, and differences in diagnostic processes (Skogli et al., 2013).

\section{Method}

This article is part of the research entitled "Trayectorias de malestar en niñas y niños diagnosticados con Trastorno de Déficit Atencional e Hiperactividad (TDAH): experiencia subjetiva y social de un sufrimiento multiforme" ("Malaise trajectories in children diagnosed with Attention Deficit and Hyperactivity Disorder (ADHD): Subjective and social experience of a multiform suffering"), conducted by the Laboratorio Transdisciplinar en Prácticas Sociales y Subjetividad (LAPSoS) (Transdisciplinary Laboratory on Social Practices and Subjectivity) 
belonging to the Facultad de Ciencias Sociales of Universidad de Chile.

\section{Data collection}

The research included three short-term ethnographies, lasting 3 to 4 months, in three educational establishments, as well as 23 interviews with both boys and girls as well as adult women and men, who had been diagnosed and/or treated by ADHD at some point in their lives. In addition, seven interviews were conducted with parents and/or caregivers and seven with mental health practitioners, as well as four discussion groups with teachers, adult men and women diagnosed with ADHD in their childhood, and health professionals.

The present article focuses specifically on the material produced in the open interviews that, oriented to "promote the production of a conversational discourse, continuous and with a certain not fragmented argumentative line" (Alonso, 2007, p. 227), were carried out to 4 boys and 3 girls between 7 and 13 years old, who had been diagnosed with ADHD and received treatment for such reason. Conducted according to a non-directive strategy, the interviews had initial slogans aimed at enquiring into their experiences related to school and daily life arising from the diagnosis and/or treatment. These interviews were carried out in the educational establishments where the interviewees attended, they were carried out by psychologists who were postgraduate students in clinical psychology, who had at least four years of previous professional experience.

\section{Participants}

The interviewees were contacted from the ethnographic fieldwork and selected based on the characteristics observed in them. In order to safeguard both the consistency and heterogeneity of the group, it was considered to include among the participants' children who: (1) received diagnosis of ADHD; (2) received or are currently under pharmacological treatment; (3) performed or are currently performing other non-pharmacological therapies; (4) presented or are currently presenting behaviors identified as disruptive in the school context by their peers and/or teachers. Regarding their socioeconomic conditions, four of them live and study in a suburban commune of the Metropolitan Region of Santiago (RM) with a Medium Low Social Priority Index (SPI), according to the criteria used by the Ministerio de Desarrollo Social (Ministry of Social Development) of the Chilean Government (2016). Among the latter, three make up family groups with lower-middle income and one belongs to a low-income family, corresponding respectively to socioeconomic levels $\mathrm{C}_{3}$ and $\mathrm{D}$, according to the classification proposed by the Asociación Chilena de Empresas de Investigación de Mercado (AIM, 2012). The remaining three participants, for their part, study in an urban commune of the RM with an SPI Low and live, as the case may be, in adjacent communes with SPI Low, Medium-Low and Medium-High, integrating each of them families from low (D), medium (C2) and medium-high (C1) socioeconomic strata.

\section{Analysis}

The material was analyzed from an analytical inductive perspective (Russel, 2006). Through a "lowerup" approach, this type of analysis allows to obtain understandings regarding a specific phenomenon from an exhaustive exploration of each case. For this, the material was analyzed in two successive stages: (1) analysis and search for explaining from a gender perspective for a case; and (2) analysis and search for explaining of a subsequent case according to a gender perspective. The explanation was accepted until a new case contradicted the explanation reached for the previous cases, in which case we looked for a new understanding that was able to clarify the set of cases. Likewise, the results of the analyzed interviews found an interpretative framework both in the interviews carried out with parents and/or main caregivers and in the observations coming from the respective ethnographies.

\section{Ethical aspects}

It should be noted that all the children interviewed agreed to participate in the research informedly and voluntarily, after having received prior authorization from their parents and/or main caregivers. In each 
case, the expression of the agreement was supported by the signing of an informed consent by the parents and/or main caregivers.

\section{Research findings}

The research findings are organized in four emerging dimensions induced from the material provided by the children. As intermediate analytical categories constructed by the researchers, they are dimensions that, adopting the form of continuums that includes diverse singular modalities, reflect a set of arrangements that, giving account of variants according to gender, emerge from the discourses of children diagnosed with ADHD with regard to their particular subjective experiences. Specifically, these dimensions concern issues related to: (1) locations; (2) abilities; (3) approaches; and (4) interactions.

Before illustrating the aforementioned dimensions, it is important to consider that, according to the children discourses, the mark of the diagnosis divides their experience in a before and an after. This is a kind of milestone that, endorsing for them a border between current experience and past experience, is sometimes linked to circumstances of school failure (deficient throughput or repetition of course, for example). However, more banally and regularly, the diagnosis is characterized in relation to "misbehaving", "be restless" or "be distracted", identifying in it the experience of non-compliance with school requirements: "pay attention", "write subjects", "speak too softly". In fact, even though some had attended schools to improve their language abilities before arriving at their schools, the current experience of difficulty would only have taken shape, both for boys and girls, in these latter establishments with regard to the formulation of the diagnosis and the prescription of treatments. Basically, what, in their experience of the problem, represents that "misbehaving" alludes, in the children discourses, to a set of non-conforming actions to the expectations demanded by adults in the school context: standing up from the chair in class, playing under the tables, having a lot of energy, speaking aloud, shouting, making jokes, not listening, be disrespectful, not write as examples. "To behave badly - B. said - is to stand up, to speak, to make heavy jokes". "To behave badly-E. said - is to throw oneself on the ground and talk to a partner." "They make me feel every day, - A. protested - that having a lot of energy is bad," and "I don't know, - he added with irony - if having a lot of energy is bad, but it's good for a career".

The definitions of "bad behavior" are multiple and do not change according to gender. Both girls and boys report that the problem lies in the gap that, on the occasion of performances disapproved by disruptive or inattentive, distances its proceeding from the approval of the adults in the school and/ or the family. However, what does vary is the place or instance in which children locate the difficulty inferred from the diagnosis.

\section{Locations}

The interviews show that the boys tend to place the complication mainly outside, in relation to the reproach of adults, towards whom they direct criticisms, are indifferent or manifest ignorance of the basis of their counterclaims. On the contrary, girls are inclined, for their part, to locate the inconvenience within, recognizing in themselves ways of being or ways of doing that, as faulty properties, inspire feelings of contrariness and sadness. "They scold me because I am slow- E. said, one of the girls, adding bitterly - I get sad when they scold me". "I behave badly, - A. claimed with anger, one of the boys -, but it's not to get kicked out of the classroom". "I didn't like to sit around listening to boring things, - B. explained scornfully, another boy, and said little confused: "I don't know why I repeated it; all of a sudden, it was here".

Beyond this variation in the locations of the problem discerned in the diagnosis, it is frequent that the experiences of both boys and girls dislocate, in turn, these general tendencies differentiated by gender. In fact, girls also criticize adults and, consequently, not only express their discontent and weariness with certain practices of their teachers in school, but also justify, on the basis of this, the nonconforming of their actions with respect to school obligation. "I stood up to sharpen my pencil and also didn't write - P. mentioned with anger - [...], because the teacher made me write a lot [...]: I'm bored!" 
Boys also locate the disadvantage within themselves, though, unlike girls, they do not allude to any defective quality identified in themselves. They express their fear that "everyone knows" about "their restlessness" and, particularly, that their classmates to "see" them taking the medication, expressing their shame and discomfort in the face of it. "I was very ashamed - V. said with disconsolation - because they were watching me and I didn't want to do it in front of everyone, but I had to do it [...]: it was just me [...] and I began to cover myself with my jacket."

\section{Abilities}

According to the place or instance where children locate the difficulty attributed to the diagnosis, the way in which they decipher the inconveniences encountered in their daily environments can be deduced. In this sense, children are inclined to consider these complications in relation to capacities that, unlike the rest of their peers, are misunderstood by adults and, above all, by their teachers in the school context. Among these abilities, they stand out their perspicacity, their speed to assimilate contents or their increased disposition of corporal energy. "Teacher $R$. is very annoying with me - A. complained - because I'm bigger". "I get bored - C. protested - because I finish the school task before".

Conversely, in the case of girls, setbacks tend to be experienced as resulting from their inadequacies or defects, among which they emphasize the slowness to write or understand subjects, the propensity in overly to converse, or excessive movement. "I can't copy [on the board] - E. complained with regret - because it took me so long: I'm slow!". "I misbehave - L. commented funnily -, because I speak with a classmate, I throw myself to the ground, I go crazy [...]: the only thing that reaches my head is a paracetamol [a pill]!”.

The foregoing, however, does not prevent that, given the occasion, the boys also describe some complication as a defect, though they safeguard that this deficiency would not be for themselves, but only for others. In fact, they suggest that they should be considered "bad" by their teachers and that, consequently, any disruption in the classroom is inevitably attributed to their actions, for which they are both the object of counterclaims and the reason for the school's claims against their parents. "I don't know what the problem is with me - V. said angrily - but they tell me every day". "But to me - B. thought mischievously - because they knew me, that I was bad, immediately they summoned my parents." Moreover, according to their perspective, those same imputed defective qualities could be transformed, by themselves, into an ability. "I went from being lazy, the only one -B. said proudly - to being the best, to working for it."

Differently, girls try to compensate their inadequacies through abilities in other areas, highlighting both their physical dexterity and agility as well as their artistic abilities expressed in dancing or singing. Likewise, they point out that, provoking them even sympathy, those limitations convene their acceptance as part of their ways of being and doing. "This other year, [my mother] is going to sign me up to do artistic gymnastics - P. said with enthusiasm and joy - [...], because I make the spider, I make the bridge, I make the handball and the wheel [referring to gymnastics corporal shapes]: I do a lot of things! My parents told me I'm hyperactive - L. said smiling - but I don't care; I like it that way: I'm like I am".

\section{Approaches}

According to the nature of these abilities, boys and girls show diverse ways of approaching, in their respective daily contexts, the difficulties linked to the experience of the diagnosis through a set of differentiated practices. Boys manifestly resort to actions that, allowing them to distance themselves from adult requirements, represent channeling aimed at "occupying their energy" or "creating their own worlds". Whether through the regular use of video games, the care of plants through gardening or the manufacture of objects, paper figurines and drawings in the classroom, they carry out tactics that, carried out by and for themselves, give them a certain "disconnection" from the demands of school. "I thought of other things - A. said enthusiastically - such as video games [...]; you can create your own things, such 
as buildings, statues, images [...]: this is my world, where I play so much [...], where I am". "For the only thing I stay still - V. commented with some irony is to surprise the cats that come into my house and [...] when I'm seeing the littles plants [...], because when I'm planting you really must have a lot of balance". Even more precisely, by restricting their problems exclusively to school, children consider that they can only occupy their energies or feel free in their homes and, in particular, on weekends. "At home - B. said - I also feel a lot of energy, but I can use it there". "The weekend - A. said - I feel free".

On the contrary, in order to deal with the complications associated with their experience of the diagnosis, girls are inclined, instead, to respond in various ways to the demands coming, according to them, from their parents and teachers, since, through these, one and the other would seek their well-being. These are approach modalities that, aimed at "keeping still", "keeping quiet" or being placed in specific places in the classroom, are strategies aimed at preventing them from carrying out actions that do not conform to the requirements of the school. "I sit down lonely in the back - E. said - [so] as not to converse". "My fingers hurt when I do my homework - P. lamented - I rest them, and [then] I'm behind." Girls do not limit themselves to a single homogeneous situation. Some of them also report practices in which they manage to display abilities not recognized by the daily demands of school. However, typically concerned by bodily abilities which, often related to dancing or singing, involve activities of an artistic or sporting nature, their performance is usually less oriented towards themselves than towards the recognition of adults. "My teachers say I have the gift of being a monkey for climbing trees so much - L. said enthused - [...]; I always like dancing, singing, and every time there are championships, I always sign up; but this timeshe said surprised - I didn't sign up, but this time the teachers chose me!"

Similarly, the boys also express efforts to achieve, by themselves, greater adjustment in their actions. However, in them it becomes more evident the participation of direct controls which, in the face of their behavior considered disruptive, are carried out by third parties in their daily contexts. "If I misbehave - A. warned - my dad is going to take me to the pre-military". "They sit me next to the teacher for [my] behaviour", B. explained. "To concentrate he added then -, [...] all the time I ask [the teacher's] permission to go to the bathroom: I get wet; I drink water; I say to myself, Oh, I'm fine; I concentrate; and I kind of get over it".

Medical and/or psychological treatments, especially the use of pharmacological treatment, have a singularly relevant place for the interviewees in relation to the modalities for dealing with their difficulties in everyday contexts. In this regard, girls tend to express approval of the care given by doctors and/or psychologists, arguing that the treatments, in particular the medication, have helped them to "behave", "be quieter", "keep silent", "do their homework" and "pass the courses". For them, psychotropic drugs represent a kind of promise for achieving the performance expectations fulfillment and the consent of adults. "When I don't take the pill - P. said - I'm crazy". "The pills have helped me to pass the year - E. said -, so that I don't talk to a classmate and to remain silent", concluding "I like to go to the doctor because he gives me pills to behave well'. Nevertheless, this does not prevent the girls from criticizing the pharmacological treatment, especially based on their negative effects on the plane of their body experience. "I feel dead with the pill - L. protested angrily - it's disgusting, I get dizzy [...], I like my mother to forget it".

Boys, on the other hand, express more decisively their rejection of medical or psychological care, which is considered a "waste of time" or, more usually, the object of indifference. Consistently, they disapprove medication and denounce its uselessness to help them achieve better behavior or greater concentration in class. In their experience, pharmacological treatment causes physical malaise (dizziness or drowning, for instances), as well as the reason for having lost qualities which, mainly related to the availability of more energy, had previously been the reason for their enjoyment. In fact, when the boys interviewed say they accept the medicines, they say they do so in order to avoid problems with adults and, in this way, not to be scolded. "It is strange that they give pills to a boy -A. exclaimed annoyed - [...]: they don't 
have superpowers!" "They still give me remedies to behave - B. denounced angry - [...] [and still] they don't do anything to me: if they throw me out of the classroom the same!" "The medicine - he concluded - is so that the teacher won't scold me he added - sometimes I sweat a lot, I get dizzy, my throat gets very dry [...], I feel very drowned when I take that pill". "With the remedy-V. pointed out with dismay - my restlessness and the desire to go out to playtime were finished".

\section{Interactions}

Just as the diverse location of the difficulties associated with diagnosis is not only connected with the heterogeneous consideration of the involved capacities, but is also linked, by the modulation of the latter, with the variable approach to resented complications, in the same way these three dimensions are articulated, in turn, with the interactive plane that, in relation to their peers, children maintain in their daily experiences according to modalities of collaboration and conflict. In fact, the social interactions reported by the interviewees with their peers are characterized by different forms of reciprocity, antagonism, stigma and exclusion. Boys tend to establish friendly relations with peers with whom they identify and, accordingly, consider themselves to be similar, while, conversely, they maintain conflicting links with respect to children whose ways of being and doing things are not, in their opinion, shared. Those "other children" have, in their experience, characteristics that make them inferiors or superiors to them: sensitive children and, therefore, devoid of the mood required for school interactions where they joke or play; smug, fighting, non-inclusive boys. "I had a friend -V. explained - that if we made those jokes we didn't accuse ourselves, we laughed, but the others were more sensitive". "You're the one who accused me - B. had told a colleague - you don't play anymore [...], [and, now,] I'm never chosen [...], I always get the bad [soccer] teams".

Children report experiencing situations of exclusion on the part of their peers, especially at the time of games characterized by challenges related to physical abilities and where leadership positions are acquired. Precisely, they regret not being able to access these positions, due to the stigma coming from the children who lead these games. As a result, some boys even prefer to avoid friendships with classmates. In addition, there are other experiences of exclusion brought about by the jokes that, on a daily basis, the children direct towards each other. When the jokes concentrate, for their great annoyance, mostly on them, the boys interviewed say they do not dare to demand their rights in the classroom, given the fear that this will eventually be interpreted as an "accusation" and catalogued as a feminine attitude on their part. Consistently, they maintain that they are not interested in maintaining friendships with girls, whom they consider annoying and prone to use, in the face of any conflict, the record of the accusation against the teachers, who always admonish them just because they are men. V. affirms - with a certain sadness - "I prefer to play alone - V. said with bitterness - because I don't have any friends at school [...]: my only friend was my grandfather". "I don't dare accuse - B. said - because I'm afraid of being called an accusatory girl". "They bothered me - A. protested - they said to me: take your pill?".

As the boys do, girls prefer to establish friendships with classmate boys and girls with similar characteristics to their own, although they are more inclined than the boys to establish collaborative links with their peers. In fact, some even consider themselves friends of "all" the girls in their school year, while, in general, they refer to carrying out, on a daily basis, common practices, such as to paint her hands, reading stories or helping each other, without excluding boys with whom they identify from their circle of friendships. "We sat together and paint our hands", E. commented. "All the girls in the course are my friends - L. said - [...], we like to play and help each other." L. specifying: "I liked to go to the PIE [School Integration Programme] in the morning it was fun, I was with some of my friends from the course who were the same as me [...], just as hyperactive".

However, the girls also show differences with those "other girls" who, because they do not share the same characteristics, are considered less quick or perspicacious. In addition, they also express a preference not to establish collaborative links with 
boys, since, as they denounce, they are frequently bothered by them and, under equal conditions, enjoy greater privileges than they do. Sometimes, they even declare to experience displeasure when sharing with their peers, choosing to distance themselves from their peer group, though always in the company of a close friend. "My classmates - P. said proudly - are a little slow, but F. and I, we are not; that's why we don't get caught". "Boys can scream and get more prizes" - L. said indignant. "Now I'm very happy E. exclaimed excited - to see the computers and to work with my classmate and not to share; because I don't like to share".

For their part, when faced with disputes with their peers, children point to alternative links of reciprocity with other peers through video games, which allow them to avoid the conflicts aroused in face-to-face games. Additionally, they also seek to establish friendships with other children in places outside the school, where they do not resent the negative mark that, according to their experience, has brought with it the diagnosis of the way in which they are seen by the environment in their daily contexts and, particularly, in their schools. According to the above, as stated by A. "[We] got angry, fought and were taken to the inspectorate - $\mathrm{A}$. said about the games with his classmates during recess, adding in contrast to video games - [...], because it's like more fun". "I like to make friends he went on, pointing proudly - [...]; I have also done good things [...]: on the subway, a child touched me [...], I had a car in my pocket [...], and I gave it to her [...]; a lady started crying because of what I did".

\section{Discussion and conclusion}

Although the ADHD category is strongly related to gender distribution, the subjective experience of the children interviewed is multiple in relation to diagnosis and, consequently, impossible to reduce to a simple binary dichotomy. The girls and boys report general tendencies that, articulating gender and diagnosis, concern the place where the difficulties associated with the diagnostic mark are located, the way of interpreting these problems, the way of approaching them in attention to adult requirements and the interaction with their peers in this respect.
The boy tended to place the complications outside, as a problem for others, while the girls tended to locate the inconveniences inside, as a problem for themselves. At the same time, while the boys preferentially interpreted the manifestations of their behavior associated with the diagnosis as qualities that, not understood in the school context, differentiate them from the rest and may find other ways of expression, the girls considered the expressions of their behavior associated with the diagnosis in the manner of their own characteristics that, representing a defect, require rectification. In addition, if the boys are inclined to address the problems associated with the diagnosis through practices aimed at channeling their abilities, the girls resorted more regularly to actions aimed at achieving an adjustment with adult demands. Finally, while the boys usually established, in the school context, conflictive relationships with their classmates, leading to experiences of exclusion, the girls tended to configure, mainly with other girls, social interactions of mutual collaboration in their schools.

However, some of the experiences of the participants dislocate these general trends in different ways. Occasionally, girls also placed outside, as problems for adults, the difficulties associated with the diagnosis, though their criticisms of the latter are formulated as justifications for their behavior. Conversely, when the boys locate within themselves the complications related to the diagnosis, they do so in relation to the shame felt in the face of the possibility of being discovered with those impairments by others and, above all, by their peers. Furthermore, if any boys discern a certain inconvenience attributed to the diagnosis of a defect, it only becomes an insufficiency for adults, since its transformation entails an ability not understood by the latter.

The girls also considered some of their alleged defects as abilities, although for them it is basically a sort of compensation for their inadequacies. Likewise, they also expressed to carry out practices that, implying their corporal abilities, constitute productive channelings. Nevertheless, in their case, such practices represent approaches aimed at getting the consent of adults, in conformance with 
the adjustment of their actions to the requirements demanded, according to their experience, by the latter. Variously, when the boys resorted to actions tending to self-regulation and, even, to the adjustment with respect to the demands coming, in their opinion, from the adults, they count above all on avoiding the possibility of receiving eventual counterclaims from them.

Finally, just as girls' relationships are not limited to collaborative relationships, boys' interactions are not limited to rivalry. While the girls also stated that they have conflictive relationships with classmates who, according to them, do not share the same characteristics and with boys who, in general, are considered to be comparatively privileged with respect to them; the boys likewise reported establishing alternative links of collaboration both with classmates through the mediation of video games and with other children found in out-of-school spaces freed from the discrimination which, according to their experience, they resent in their schools.

Consequently, according to the expressions of the participants in this study, not only are the experiences of disagreement regarding ADHD far from being uniform, but, in view of this, they acquire forms differentiated according to gender, accounting, in turn, for modulations and variants of gender. In other words, boys and girls resist, each in their own way, a complete uniform subjection to binary gender prescriptions, as well as to the demands that, equally according to gender, are established by adults, especially at school level. In fact, this is particularly sensitive when observing the place given by them to the game that, in contradiction with adult norms, subverts the schooling mandate according to a heteronomous order.

However, neither does the game result, in the experience of the participants, totally immune to gender variations. If the boys use the game to create "own" worlds, connect with their peers according to alternative modalities ignored by the conflict and avoid the mark derived from the diagnosis; the girls tended to use games to develop skills different from those required at school, seeking to shift adult recognition to other spheres, in addition to seeking collaborative links with other children. Even at play, the experiences of the boys and girls interviewed show that they are, in one way or another, regularly referring to adult discourses and practices. Whether in acceptance, submission or justification of school, family and/or medical practices tending to regulate and/or normalize actions considered disruptive, as well as in the various modes of criticism and the creation of alternative universes contrary to adult requirements, it is possible to observe that what the children interviewed speak and do is inevitably articulated in reference to contexts that, characterized by dependency relations, involve an unequal distribution of power with adults. Indeed, children's discourse is captured in an asymmetric discursive with respect to adult discourse. In this way, giving rise to the children's discourse would, in turn, be the (re)production of an adult discourse of childhood (Burman, 2017).

The foregoing is precisely what epidemiological studies are unaware of. Said in other words, the behaviors that constitute "bad behavior" in children's experience are defined as such according to what impedes the development of school activities established in conformance with the logic of achievement and performance, that is, in accordance with an order of adult performance. Although the general tendencies regarding gender found in the experiences of the children seem to be in continuity with some of the observations emanating from the field of epidemiology and psychiatry, such coincidences regarding gender variations do not seem to be intrinsic qualities of the children.

The participant boys usually located the difficulties associated with the diagnosis as a problem for others, interpreted the characteristics linked to the diagnosis as an ability, or managed to channel the problems into practices oriented towards themselves; and on the other hand, the girls located the difficulties in themselves, interpreted them as a defect or were oriented towards fulfilling the expectations of the adult world. All this could certainly be considered in correspondence with what is sustained in such studies regarding the perception of girls about themselves as more inefficient and with less self-esteem than boys (Garza-Morales; Núñez-Villaseñor; VladimirskyGuiloff, 2007; Rucklidge; Tannock, 2001), and, in 
turn, with studies claiming that girls would be more prone than boys to suffer from psychiatric pathologies (Dalsgaard et al., 2002; Gershon, 2002; Rucklidge; Tannock, 2001). However, such experiences would be linked to the ways in which the children decipher the problems associated with the diagnosis and the place in which they place the difficulties in relation to the practices and discourses of adults.

At the same time, boys and girls do not experience in a differentiated way the difficulties linked to the diagnosis in terms of greater presence of inattentive or hyperactive behaviors, in some and others, as sustained by previous studies (Gershon, 2002; Hasson; Fine, 2012; Rucklidge, 2006; Seidman et al., 2005; Vélez et al., 2008). Children report difficulties in their daily contexts, both in relation to their hyperactivity and inattention. What is expressed as differences are the ways in which the boys and girls interviewed approach the problems associated with ADHD in the school context, being the conflictive ones around the disruptive behaviors the ones that prevail. Even, epidemiological studies that maintain that in adolescence girls would be more diagnosed with ADHD than boys (De la Barra et al., 2013) show that hyperactivity or impulsivity continues to be the most prevalent contingent at such age level, as opposed to attention.

Likewise, the experiences of the children interviewed in terms of social interactions with their peers show them to be characterized by both conflict and collaboration, which leads to experiences of exclusion and stigma in one and the other, however, how they experience such interactions in their daily contexts vary depending on gender. This manner, it could not be argued that girls naturally tend to establish lower quality, conflictive and aggressive interpersonal relationships, as the revised literature holds (Biederman et al., 20o2; Blachman; Hinshaw, 2002; Guerrero et al., 2017; Mikami; Lorenzi, 2011; Sciberras; Ohan; Anderson, 2012).

The above shows that the gender differences present in the ADHD diagnosis are constituted by sociocultural dimensions that cannot be reduced to a list of present or absent natural conditions to be proved. The gender differences sustained by epidemiological studies would reduce the subjective experience of children to a set of preformed characteristics, as natural conditions, as opposed to cultural dimensions as variables "external" to the diagnosis, ignoring the constitutive condition of the sociocultural dimensions in the experience of the diagnosis. In this way, such studies configure an epistemological bias that, in addition to naturalizing the disorder by configuring genetically prejudiced conditions, establishes categories of adult demand as orders of naturalized reality cognitive adult abilities within a performance evaluation context.

The subjective experiences of the boys and girls express that the relationships between diagnosis of ADHD and gender cannot be reduced to a binary experience in which the masculine and feminine correspond to natural conditions. Children position themselves in a differentiated manner in relation to adult demands, and there are the everyday contexts the ones that regulate, normalize or permit the deployment of the multiple and singular ways of positioning - submitting or resisting - children in relation to such normative orders. Such forms of subjection or subversion emerge when children's experiences are considered from a perspective that understands that their discourses and practices are constituted, even although not absolutely, by a performance bias of adult demands in the context of submission to performance and where behavioral problems prevail.

The findings of our study raise questions that, even beyond the children's own experience of ADHD, concern the ways in which the gender dimension might even participate in the subjective experience of adults diagnosed with ADHD during childhood. Specifically, it becomes relevant to explore the subjective experience not only in contingent terms of the daily experience of adults, but also in terms of the possible marks left during childhood by the normative orders of gender mobilized in relation to ADHD. In the same way, our research invites to inquire into the relationships that, both in childhood and adulthood, maintain ADHD and gender in Chile, also including the exploration of other sociocultural dimensions involved such as social class and race/ ethnicity. 
References

AIM - ASOCIACIÓN INVESTIGADORES

DE MERCADO. Nuevo modelo de grupos

socioeconómicos. Santiago, 2012. Disponível em:

<https://bit.ly/2C3hEMk>. Acesso em: 19 dez. 2018.

ALONSO, L. E. Sujetos y discurso: el lugar de la entrevista abierta en las prácticas de la sociología cualitativa. In: DELGADO, J. M.; GUTIÉRREZ, J. M. Métodos y técnicas cualitativas de investigación en ciencias sociales. Madrid: Síntesis, 2007. p. 225-240.

APA - AMERICAN PSYCHIATRIC ASSOCIATION. DSM IV: breviario criterios diagnósticos.

Barcelona: Masson, 2014.

APABLAZA, M. Prácticas "psi” en el espacio escolar: nuevas formas de subjetivación de las diferencias. Psicoperspectivas, Vina del Mar, v. 16, n. 3, p. 5263, 2017. Disponível em: <https://bit.ly/2sjZEsw>. Acesso em: 31 out. 2018.

BEHROUZAN, O. The Prozac diaries: psychiatry and generational memory in Iran. Stanford: Stanford University Press, 2016.

BERGEY, M.; CONRAD, P. The rise and transformation of ADHD in the United States. In: BERGEY, M. et al. Global perspectives on ADHD: social dimensions of diagnosis and treatment in 16 countries. Baltimore: Johns Hopkins University Press, 2018. p. 9-33.

BIEDERMAN, J. et al. Influence of gender on attention deficit hyperactivity disorder in children referred to a psychiatric clinic. The American Journal of Psychiatry, Arlington, v. 159, n. 1, p. 36-42, 2002.

BIEDERMAN, J. et al. Adult psychiatric outcome of girls with attention deficit hyperactivity disorder: 11-year follow-up in a longitudinal casecontrol study. The American Journal of Psychiatry, Arlington, v. 167, n. 4, p. 409-417, 2010.
BIEHL, C.; GOOD, N.; KLEINMAN, A. Introduction: rethinking subjectivity. In: BIEHL, C.; GOOD, N.; KLEINMAN, A. (Ed.). Subjectivity. London: University of California Press, 2007. p. 1-23.

BLACHMAN, D.; HINSHAW, S. Patterns of friendship among girls with and without attention-deficit/hyperactivity disorder. Journal of Abnormal Child Psychology, New York, v. 3o, n. 6, p. 625-640, 2002.

BLACKMAN, L. et al. Creating subjectivities. Subjectivity, Houndmills, v. 22, n. 1, p. 1-27, 2008.

BURMAN, E. Deconstructing developmental psychology. Abingdon: Brunner-Routledge, 2017.

CARLSON, C. L.; TAMM, L.; GAUB, M. Gender differences in children with ADHD, ODD, and co-occurring ADHD/ODD identified in a school population. Journal of the American Academy of Child and Adolescent Psychiatry, New York, v. 36, n. 12, p. 1706-1714, 1997.

CHILE. Ministerio de Salud. Normas técnicas para el diagnóstico y tratamiento de los trastornos hipercinéticos en la atención primaria. Santiago, 1998.

CHILE. Ministerio de Salud. Guía clínica: atención integral de niñas/niños y adolescentes con trastorno hipercinético/trastorno de la atención (THA). Santiago, 2008. Disponível em: <https://bit.ly/2FndIt2>. Acesso em: 5 ago. 2018.

CHILE. Ministerio de Educación. Déficit atencional: guía para su comprensión y desarrollo de estrategias de apoyo, desde un enfoque inclusivo, en el nivel de educación básica. Santiago, 2009.

CHILE. Ministerio de Salud. Prioridad programática: niñas, niños y adolescentes con trastorno hipercinético/de la atención (THA). Santiago, 2011. Disponível em: <https://bit.ly/2FhcMaF>. Acesso em: $1^{0}$ nov. 2018. 
CHILE. Ministerio de Desarrollo Social. Región Metropolitana de Santiago: índice de prioridad social de comunas 2015. Santiago, 2016.

Disponível em: <https://bit.ly/2gvXuoz>. Acesso em: 10 jan. 2019.

CHILE. Ministerio de Educación. Nueva Plataforma Programa de Integración Escolar. Santiago, 2017. Disponível em: <https://bit.ly/2RhTNms >. Acesso em: 8 set. 2018.

COLES, E. et al. Exploring the gender gap in referrals for children with ADHD and other disruptive behavior disorders. Journal of Attention Disorders, Thousand Oaks, v. 16, n. 2, p. 101-108, 2012.

CONRAD, P.; SINGH, I. Reflections on ADHD in a global context. In: BERGEY, M. et al. Global perspectives on $A D H D$ : social dimensions of diagnosis and treatment in 16 countries. Baltimore: Johns Hopkins University Press, 2018. p. 376-390.

DALSGAARD, S. et al. Conduct problems, gender and adult psychiatric outcome of children with attention-deficit hyperactivity disorder. British Journal of Psychiatry, London, v. 181, n. 5, p. 416421, 2002.

DE LA BARRA, F. E. et al. Epidemiology of ADHD in Chilean children and adolescents. Attention Deficit and Hyperactivity Disorder, Wien, v. 5, n. 1, p. 1-8, 2013.

GARZA-MORALES, S.; NÚÑEZ-VILLASEÑOR, P. S.; VLADIMIRSKY-GUILOFF, A. Autoestima y locus de control en niños con trastorno por déficit de atención con hiperactividad. Medigraphic Artemisa, Ciudad de México, v. 64, p. 231-239, 2007.

GAUB, M.; CARLSON, C. L. Gender differences in ADHD: a meta-analysis and critical review. Journal of the American Academy of Child and Adolescent Psychiatry, New York, v. 36, n. 8, p. 1036-1045, 2007.
GERSHON, J. A meta-analytic review of gender differences in ADHD. Journal of Attention

Disorders, Thousand Oaks, v. 5, p. 143-154, 2002.

GUERRERO, R. et al. La personalidad eficaz en adolescentes diagnosticados de trastorno por déficit de atención con hiperactividad (TDAH): diferencias de género. Revista de Orientación Educacional, Valparaíso, v. 31, n. 59, p. 38-52, 2017.

HART, N.; GRAND, N.; RILEY, K. Making the grade: the gender gap, ADHD, and the medicalization of boyhood. In: ROSENFELD, D.; FAIRCLOTH, C. (Ed.). Medicalized masculinities. Philadelphia: Temple University Press, 2006. p. 132-165.

HASSON, R.; FINE, J. Gender differences among children with ADHD on continuous performance test: a meta-analytic review. Journal of Attention Disorders, Thousand Oaks, v. 16, n. 3 , p. 190-198, 2012.

HERRERA, J. F.; REYES, L.; RUIZ, C. M. Escuelas gobernadas por resultados: efectividad escolar y políticas educacionales de la transición democrática. Psicoperspectivas, Vina del Mar, v. 17, n. 2, p. 163-174, 2018.

MATUS, C.; ROJAS, C. Etnografía de la normalidad. In: ASSAÉL, B.; VALDIVIA, A. (Ed.). Lo cotidiano en la escuela: 40 años de etnografía escolar en Chile. Santiago: Editorial Universitaria, 2018. p. 255-274.

MIKAMI, A. Y.; LORENZI, J. Gender and conduct problems predict peer functioning among children with attention-deficit/hyperactivity disorder. Journal of Clinical Child and Adolescent Psychology, London, v. 4o, n. 5, p. 7777-786, 2011.

MONTIEL-NAVA, C.; MONTIEL-BARBERO, I.; PEÑA, J. Presentación clínica del trastorno con déficit de atención-hiperactividad como función de género. Investigación Clínica, Maracaibo, v. 48, n. 4, p. 459-468, 2007. 
NAKAMURA, E. Les problèmes de santé mentale durant l'enfance à Santos (Brésil) et Paris:

l'interdépendance entre biologique et social dans les comportements des enfants. In: LEMERLE, S.; REYNAUD-PALIGOT C. (Coord.). La biologisation $d u$ social: discours et pratiques. Paris: Presses Universitaire de Paris-Nanterre, 2017. p. 161-18o.

NEWCORN, J. H. et al. Symptom profiles in children with ADHD: effects of comorbidity and gender. Journal of the American Academy of Child and Adolescent Psychiatry, New York, v. 2, n. 40, p. 137-146, 2001.

PEÑA, M.; ROJAS, P.; ROJAS, S. ¿Cómo diagnosticar un niño? Diagnóstico del trastorno de déficit atencional con hiperactividad desde una perspectiva discursiva crítica. Athenea Digital, Bellaterra, v. 15, n. 1, p. 91-110, 2015. Disponível em: <https://bit.ly/2CeCUPq>. Acesso em: 5 nov. 2015.

POLLACK, W. Real boys: rescuing our sons from the myths of boyhood. New York: Holt, 1999.

ROJAS, S.; ROJAS, P.; PEÑA, M. From problematic children to problematic diagnosis: the paradoxical trajectories of child and adolescent ADHD in Chile. In: BERGEY, M. R. et al. (Ed.). Global perspectives on $A D H D$ : social dimensions of diagnosis and treatments in sixteen countries. Baltimore: Johns Hopkins University Press, 2018. p. 310-321.

RUCKLIDGE, J. J. Gender differences in neuropsychological functioning of New Zealand adolescents with and without attention deficit hyperactivity disorder. International Journal of Disability, Development and Education, Abingdon, v. 53, n. 1, p. 47-66, 2006.

RUCKLIDGE, J. J. Gender differences in attentiondeficit/hyperactivity disorder. Psychiatric Clinics of North America, Philadelphia, v. 33, n. 2, p. 357373, 2010.

RUCKLIDGE, J. J.; TANNOCK, R. Psychiatric, psychosocial, and cognitive functioning of female adolescents with ADHD. Journal of the American Academy of Child and Adolescent Psychiatry, New York, v. 40, n. 5, p. 530-540, 2001.

RUSSEL, B. H. Research methods in anthropology: qualitative and quantitative approaches. Oxford: Altamira Press, 2006.

SCIBERRAS, E.; OHAN, J.; ANDERSON, V. Bullying and peer victimisation in adolescent girls with attention-deficit/hyperactivity disorder. Child Psychiatry and Human Development, New York, v. 43, n. 2, p. 254-270, 2012.

SEIDMAN, L. J. et al. Impact of gender and age on executive functioning: do girls and boys with and without attention deficit hyperactivity disorder differ neuropsychologically in preteen and teenage years? Developmental Neuropsychology, London, v. 27, n. 1, p. 79-105, 2005.

SINGH, I. Doing their jobs: mothering with Ritalin in a culture of mother-blame. Social Science and Medicine, Oxford, v. 59, n. 6, p. 1193-1205, 2004.

SKOGLI, E. W. et al. ADHD in girls and boys: gender differences in co-existing symptoms and executive function measures. BMC Psychiatry, London, v. 13, n. 1, p. 242-298, 2013.

TIMIMI, S.; TAYLOR, E. ADHD is best understood as a cultural construct. British Journal of Psychiatry, London, v. 184, n. 1, p. 8-9, 2004.

TIMIMI, S. et al. A critique of the international consensus statement on ADHD. Clinical Child and Family Psychology Review, New York, v. 7, n. 1, p. 59-63, 2004.

VÉLEZ, A. et al. Prevalencia de trastorno por déficit de atención con hiperactividad en escuelas de Bogotá, Colombia. Acta Neurológica Colombiana, Bogotá, v. 24, n. 1, p. 6-12, 2008.

VERGARA, A. et al. Childhood in children's eyes: analysis of a discourse among middle-income sectors in Santiago, Chile. Children and Society, 
Hoboken, v. 28, n. 2, p. 81-92, 2014. Disponível em: <https://bit.ly/2D1TrI8>. Acesso em: 12 set. 2018.

WILLIAMSON, D.; JOHNSTON, C. Gender differences in adults with attention-deficit/hyperactivity disorder: a narrative review. Clinical Psychology Review, Tarrytown, v. 40, p. 15-27, 2015.

WODAK, R.; MEYER, M. (Ed.). Methods of critical discourse analysis. London: Sage, 2001.

\section{Authors' contribution}

Uribe and Abarca-Brown performed a literary review and, with Radiszcz, composed the article. López-Contreras conducted part of the fieldwork and translated the article. All the authors analyzed fieldwork material.

Received: $12 / 08 / 2018$

Approved: 01/03/2019 